\title{
Proteomic Studies on Protein Oxidation in Bonito (Katsuwonus pelamis) Muscle
}

\author{
Yousuke Kinoshita ${ }^{1}$, Tsutomu Sato ${ }^{1}$, Hirotaka Naitou ${ }^{2}$, Norio OHashi ${ }^{2}$ and Shigenori Kumazawa ${ }^{1 *}$ \\ ${ }^{1}$ Department of Food and Nutritional Sciences, University of Shizuoka, 52-1 Yada, Suruga-ku, Shizuoka 422-8526, Japan \\ ${ }^{2}$ Institute for Environmental Sciences, University of Shizuoka 52-1, Yada, Suruga-ku, Shizuoka 422-8526, Japan
}

Received October 4, 2006; Accepted January 22, 2007

\begin{abstract}
Recently, there have been advances in the genome analysis of numerous living organisms, including humans. In one post-genome study, the term "proteomics" has attracted much attention. Although proteomics have been widely investigated in the medical and pharmaceutical fields, only a few proteomic studies in the field of food sciences have been reported. Therefore, in this study, proteomic techniques were applied to an analysis of quality evaluations of fish during storage. Specifically, detailed changes in fish proteins during storage were analyzed using two-dimensional electrophoresis and mass spectrometry. We investigated the early oxidative proteins of bonito muscle during storage, and several proteins were identified by homology search using the NCBI genome database. Thus, the proteomic technique is available to the field of food science.
\end{abstract}

Keywords: bonito, proteomics, FTSC, storage, protein carbonyls

\section{Introduction}

Recently, there have been concerns regarding problems in food safety such as toxic components, deterioration, and mislabeling. These issues are motivated by the need to increase the profit for foodstuffs by increasing production capacity, decreasing quality maintenance and stabilizing the product supply. As a consequence, these actions have caused damage to consumer health. Thus, it is necessary to show consumer information on the products and to develop more detailed studies on food safety (Cserháti et al., 2005; Harlizius et al., 2004; Onodera and Kim, 2006; Pafundo et al., 2005; Terry et al., 2005). Another recent development is the advancements in genome analyses of numerous living organisms, including humans. The term "proteomics" used in one of the post-genome studies has also attracted much attention. Although proteomics have been widely investigated in the medical and pharmaceutical fields, only a few proteomic studies in the field of food sciences have been reported (Hanash, 2003; Martinez and Friis, 2004; Morzel et al., 2006; Natarajan et al., 2006). Therefore this study applied proteomic techniques to the analysis of the quality evaluation of fish during storage. Specifically, detailed changes in fish proteins during storage were analyzed using two-dimensional (2D) electrophoresis and mass spectrometry (MS). Proteome analysis has been already reported to clarify the oxidative changes in protein composition due to the process of deterioration in several fish species such as rainbow trout, cod, and sea bass (Kjærsgård and Jessen, 2003; Martinez and Friis, 2004; Morzel et al., 2000; Morzel et al., 2006; Verrez-Bagnis et al., 2001). However, no study has identified easily oxidized proteins using a genome database.

* To whom correspondence should be addressed.

E-mail: kumazawa@smail.u-shizuoka-ken.ac.jp
Freshness is one of the important food quality standards. If the storage conditions for fish are not suitable, textural changes, odor, and a loss of moisture causes the quality to deteriorate (Ando et al., 1991; Jiang et al., 1990; Papa et al., 1996; Seki and Watanabe, 1994; Sikorski and Sun 1984; Tejada et al., 1996; Tsuchiya et al., 1992). Fish muscle, consisting primarily of proteins and lipids, is especially susceptible to oxidation due to its substantial polyunsaturated fatty acid content (Frankel, 1998; Richards and Dettmann, 2003; Saeed and Howell, 2002).

Alternately, proteins are modified by oxidative deterioration to form the carbonyl structure (Shacter, 2000; Levine and Stadtman, 2001). Several methods to detect the oxidized proteins have been reported (Davies, 1987; Davies et al., 1987; O'Shannessy et al., 1984; Saeed et al., 1990; Soyer and Hultin, 2000; Stadtman, 1990). In the present study, 2,4-dinitrophenyl hydrazine (DNPH) and fluorescein thiosemicarbazide (FTSC) were used to detect the protein carbonyls (PC). DNPH and FTSC have also been widely used in the detection of carbonyl structures (Kjærsgård and Jessen, 2004; Levine et al., 1990; Nakamura and Goto, 1996; Srinivasan and Hultin, 1995; Srinivasan and Hultin, 1997). FTSC-labeled proteins in particular can be detected without Western blotting (Kabisch et al., 1999; Jung et al., 1997). Previous reports on protein oxidation and carbonylation in fish muscle used different methods, such as electrophoresis and Western blotting (Srinivasan and Hultin, 1995; Kjærsgård and Jessen, 2004).

Yaizu is an active, high-volume fishing port in Shizuoka, Japan. About $70 \%$ of its catches consist of bonito. The aim of this study is to elucidate the pattern of protein oxidation in bonito muscle obtained from this port, and to reveal which proteins are easily carbonylated. We expect that any indicators of protein deterioration elucidated by this study will be applied to evaluate the freshness of fish. 


\section{Materials and Methods}

Materials The sample, brine-frozen bonito (Katsuwonus pelamis), was obtained from a fish market Yaizu, Japan. The frozen bonito was separated with respect to the storage period. White muscle was removed and stored for 4 days at $15^{\circ} \mathrm{C}$. The stored samples were kept at $-80^{\circ} \mathrm{C}$ until analysis and defrosted as needed; samples were not refrozen. The reagents used for this study were special or HPLC-grade chemicals.

Determination of TBARS Contents and PC Contents Thiobarbituric acid-reactive substances (TBARS) contents were determined by the thiobarbituric acid method (Kosugi et al., 1992). PC contents were determined by the DNPH method (Nakamura and Goto, 1996).

Protein Extraction and Determination for Electrophoresis Muscle tissue extracted from bonito were prepared immediately after defrosting in running water, and all steps were conducted on ice. Muscle was homogenized (Sample grinding kit, Amersham Biosciences, NJ, U.S.A.) in $200 \mu \mathrm{L}$ of the extraction buffer [7 M urea, $2 \mathrm{M}$ thiourea, 4\% CHAPS, $1 \mathrm{M}$ Tris-HCl, $\mathrm{pH} 8.5,3 \%$ benzonaze (Merck, Darmstadt, Germany), $2 \%$ protease inhibiter (Amersham Biosciences, NJ, U.S.A.)] for 5 min on ice. All homogenates were centrifuged for $5 \mathrm{~min}$ at $10,000 \mathrm{~g}$, at $4^{\circ} \mathrm{C}$. The supernatants were collected and used for further analysis. The total protein concentration in the extracts was determined by Coomassie protein assay (Protein assay kit, Bio-Rad, CA, U.S.A.).

Labeling of Oxidized Proteins with FTSC for Electrophoresis Protein carbonyls were labeled with FTSC. About $50 \mu \mathrm{g}$ of protein in $50 \mu \mathrm{L}$ of the extraction buffer was incubated with $30 \mu \mathrm{L}$ of potassium acetate buffer $(1 \mathrm{M}, \mathrm{pH}$ 4.6), $5 \mu \mathrm{L}$ of $\mathrm{FTSC}(0.1 \%$ in DMSO) and $15 \mu \mathrm{L}$ of ultra pure water for $2 \mathrm{~h}$ at room temperature in the dark. The proteins were precipitated by 2D clean-up kit (Amersham).

SDS-PAGE After labeling with FTSC, protein pellets were dissolved in the extraction buffer. Excess CHAPS were removed from the sample solution by ultrafiltration (VIVASPIN 500, Sartorius AG, Göttingen, Germany), The samples stored for $0,1,2,3$, and 4 days were separated on SDS-PAGE using 5-10\% gradient gel, e-PAGE (Atto, Tokyo, Japan) in the dark. SDS molecular weight markers (Sigma, MO, U.S.A.) were used for the molecular standard.

$2 D-G E$ Two-dimensional gel electrophoresis (2D-GE) was carried out using ZOOM IPGRunner system (Invitrogen, CA, U.S.A.). Total protein pellets $(50 \mu \mathrm{g})$ were dissolved in the rehydration buffer $[7 \mathrm{M}$ urea, $2 \mathrm{M}$ thiourea, 4\% CHAPS, $1 \mathrm{M}$ Tris-HCl, pH 8.5, 0.5\% ZOOM carrier ampholytes 3-10 (Invitrogen, CA, U.S.A.), $20 \mathrm{mM}$ dithiothreitol (DTT), and bromophenol blue]. 2D-GE analyses were performed in the dark. The sample solution was applied to ZOOM drystrips (Invitorogen), which are $7 \mathrm{~cm}$ long with nonlinear $\mathrm{pH}$ gradients of $3-10$ or $6-10$, and was rehydrated overnight in the dark. The first dimensional run of isoelectric focusing (IEF) was performed during 1.2 $\mathrm{h}$ with a gradually increasing voltage. After the proteins were separated in the first dimension, the strips were equilibrated for $15 \mathrm{~min}$ in the equilibration buffer $[1.8 \mathrm{~mL}$ of $1 \times$ NuPAGE LDS sample buffer (Invitrogen) and $200 \mu \mathrm{L}$ of NuPAGE sample reducing agent $(10 \times)$ (Invitrogen)] and $15 \mathrm{~min}$ in the alkylation buffer $[125 \mathrm{mM}$ iodoacetamide and $2 \mathrm{~mL}$ of $1 \times \mathrm{NuPAGE}$ LDS sample buffer (Invitrogen)]. The equilibrated strips were separated according to molecular size in the second dimension on SDS-PAGE using precast gel, NuPAGE 4-12\% Bis-Tris ZOOM gel (Invitrogen).

Samples for Pick Up The protein samples for identification were pre-fractionated using ZOOM IEF fractionator (Invitrogen). The proteins were separated according to isoelectric point ( $\mathrm{pI}$ range $<3.0,3.0-4.6,4.6-5.4,5.4-$ $6.2,6.2-7.0,7.0-10.0$, and $10<)$. And then the fractions ( $\mathrm{pI}$ range of $5.4-6.2,6.2-7.0,7.0-10.0$, and $10<$ ) were mixed, and applied to IEF as described above using ZOOM strip, $7 \mathrm{~cm}$ long and with $\mathrm{pH}$ gradient of 6-10 (Invitorogen). The proteins were separated on 10\% SDS-PAGE using BindSilane (Amersham Biosciences).

Detection of Proteins Total proteins were stained by Sypro Ruby (Invitorogen). The pattern of total proteins and the fluorogram of FTSC-labeled proteins were analyzed using the fluorescence image scanner, Typhoon 9400 (Amersham Biosciences).

Identification of Oxidized Proteins For identification of FTSC-labeled proteins, each spot was picked from gels using Ettan spot picker with image analyzing software (ImageMaster; Amersham Biosciences), and the proteins were in-gel digested with trypsin. The resultant peptide fragments were analyzed on MALDI-TOF/TOFMS (Bruker Daltonics, Bremen, Germany). Proteins were determined either by peptide mass fingerprinting (PMF) or by MS/ MS fragment ions using the NCBI database.

\section{Results}

Oxidative Deterioration Figure 1 shows the TBARS of the muscle tissue proteins of bonito during a 4-days storage period at $15^{\circ} \mathrm{C}$. TBARS of 0 -day was $0.08 \pm 0.01 \mu \mathrm{mol} /$ $\mathrm{g}$, and thereafter it increased with the number of storing days. TBARS of 4 -day storage was $0.52 \pm 0.14 \mu \mathrm{mol} / \mathrm{g}$.

Figure 2 shows the PC of the muscle tissue proteins

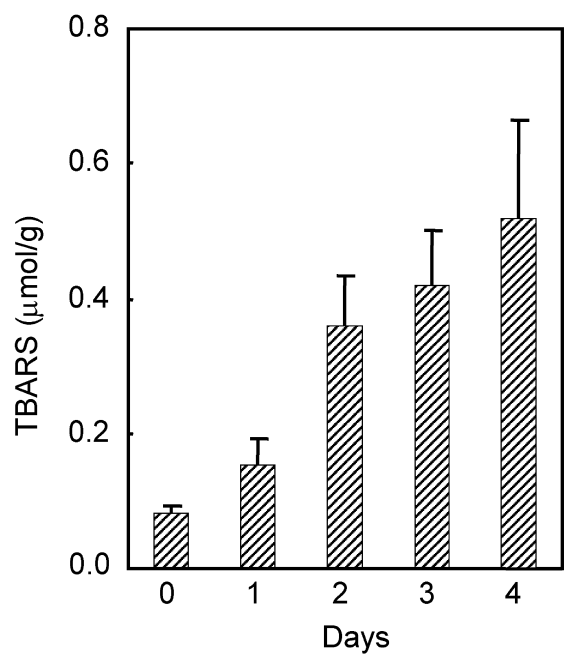

Fig. 1. TBARS of muscle tissue proteins of bonito during 4 day storage period at $15^{\circ} \mathrm{C}$. 


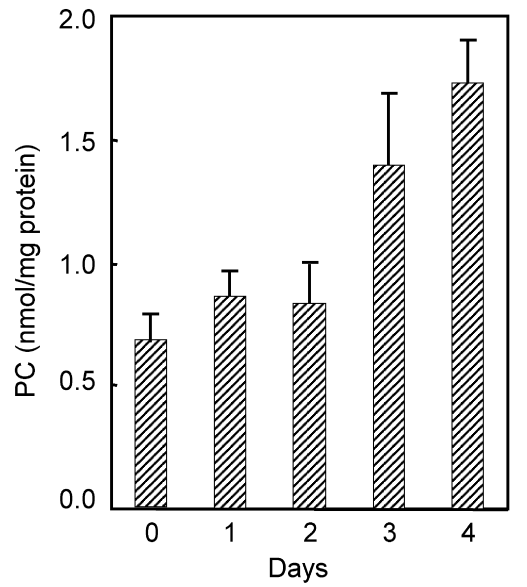

Fig. 2. Protein carbonyls (PC) of muscle tissue proteins of bonito during 4 day storage period at $15^{\circ} \mathrm{C}$.
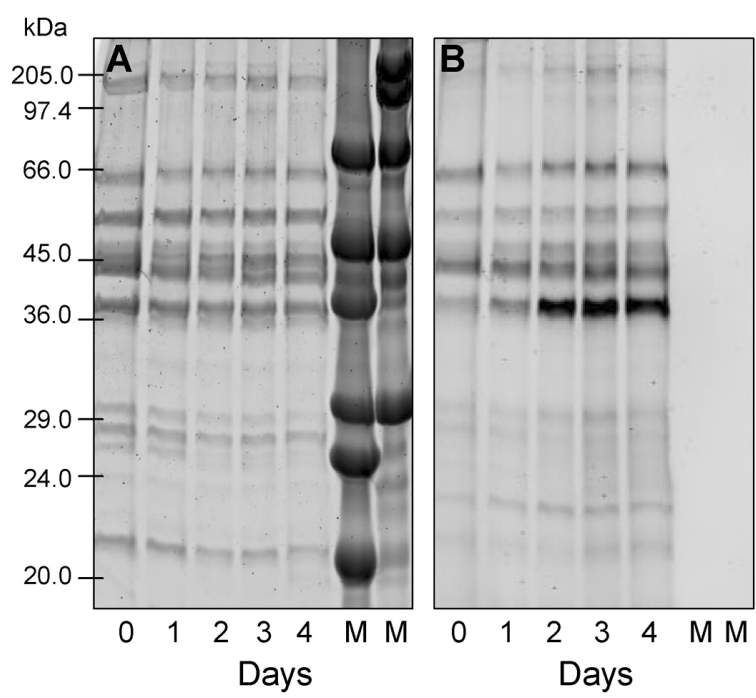

Fig. 3. 5-10\% SDS-PAGE of muscle tissue proteins of bonito during 4 day storage period at $15^{\circ} \mathrm{C}$ : (A) Sypro Ruby stained patterns showing the amount of protein applied; (B) fluorogram showing FTSC-labeled protein carbonyls. $\mathrm{M}$ indicates molecular weight standard protein markers.

during a 4-day storage period at $15^{\circ} \mathrm{C}$. PC of 0 -day was $0.67 \pm 0.12 \mathrm{nmol} / \mathrm{mg}$ protein, and thereafter the value also increased with the number of storing days as observed for TBARS. PC of a 4 -day storage was $1.73 \pm 0.17 \mathrm{nmol} / \mathrm{mg}$ protein.

SDS-PAGE Figure 3 shows the SDS-PAGE of the muscle tissue proteins of bonito during a 4-day storage period at $15^{\circ} \mathrm{C}$. Figures $3 \mathrm{~A}$ and $\mathrm{B}$ show total and FTSClabeled proteins, respectively. As shown in Fig. 3A, changes in total proteins with increasing storage periods were not definitely observed. But in FTSC-labeled proteins (Fig. 3 B), the band intensity of approximately $36 \mathrm{kDa}$ was observed to become thicker as the number of storing days increased.

2D-GE and Identification of Proteins Figure 4 shows the 2D-GE of the muscle tissue proteins of bonito stored for 4 days at $15^{\circ} \mathrm{C}$. Figures $4 \mathrm{~A}$ and $\mathrm{B}$ show total and FTSC-
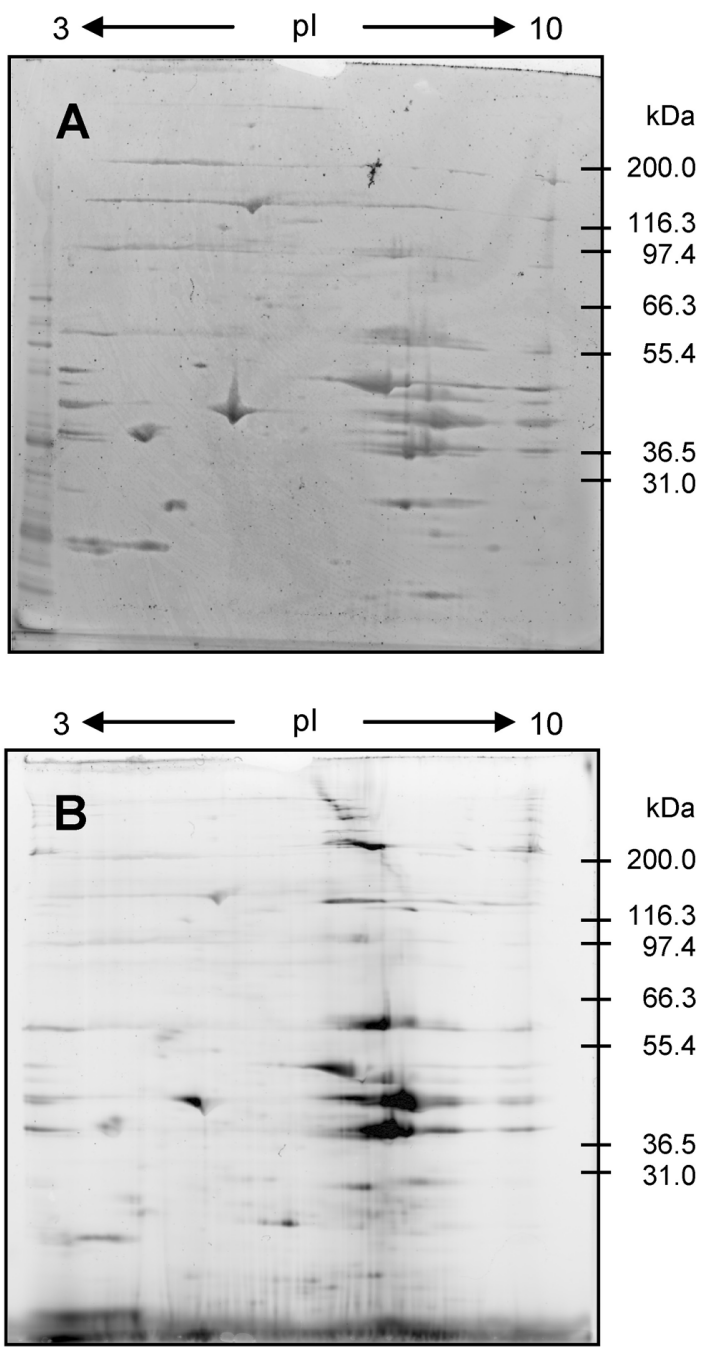

Fig. 4. 2D-GE of muscle tissue proteins of bonito stored for 4 days at $15^{\circ} \mathrm{C}$ : (A) Sypro Ruby stained patterns showing the amount of protein applied; (B) fluorogram showing FTSC-labeled protein carbonyls. FTSC-labeled proteins separated by nonlinear pH 3-10 IPG dry strip, followed by a size separation on $4-12 \%$ SDS-PAGE.

labeled proteins, respectively. As shown in Fig. 4B, FTSClabeled proteins were markedly detected in the range of approximately $36-60 \mathrm{kDa}$ and $\mathrm{pI} 6-9$. Thus, this range (36$60 \mathrm{kDa}$ and pI 6-9) was thoroughly compared between storing days. Figure 5 shows the enlargement $(30-70 \mathrm{kDa}$ pI 6-9) of 2D-GE of the muscle tissue proteins of bonito stored at $15^{\circ} \mathrm{C}$; Sypro Ruby detected total proteins are shown on the left, while FTSC-labeled proteins are visible on the right. As is evident from Fig. 5, definite changes in protein spots between storage days were not observed, while the intensity of FTSC-labeled protein spots was enhanced as the number of storing days increased.

In order to analyze the oxidized proteins in more detail, the FTSC-labeled proteins were carried out by pre-fractionation and were separated using narrow range (pI 6-10) strip gels. Figure 6 shows the 2D-GE pattern of the muscle tissue proteins of bonito stored for 4 days using narrow range (pI 6-10). Several spots were observed and five spots (No. 1-5) were picked up for identification. The 


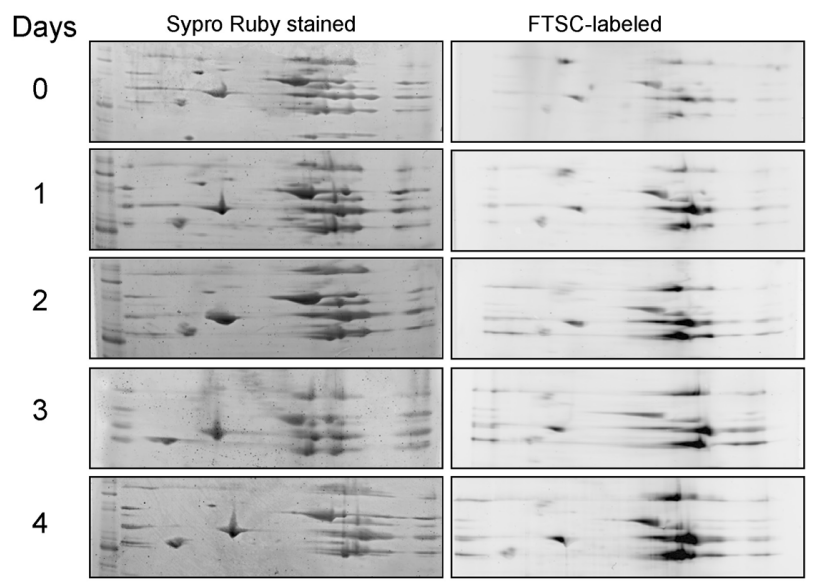

Fig. 5. Enlargement (M.W $=30-70 \mathrm{kDa})$ of $2 \mathrm{D}-\mathrm{GE}$ of muscle tissue proteins of bonito during 4 day storage period at 15 ${ }^{\circ} \mathrm{C}$ : (left) Sypro Ruby stained patterns; (right) fluorogram of FTSC-labeled proteins.

spots picked up were subject to in-gel digestion, followed by identification using MS analyses. The results are shown in Table 1.

\section{Discussion}

Initially, the oxidative deterioration process of bonito muscle proteins under storage was investigated by TBARS and protein carbonyl determination. TBARS has been used as an index of the degree of lipid peroxidation (Frankel, 1998; Richards and Dettmann, 2003; Saeed and Howell, 2002; Kosugi et al., 1992), whereas PC has been used as an index of the degree of protein oxidation (Kjærsgård and Jessen, 2004; Levine et al., 1990; Levine and Stadtman, 2001; Nakamura and Goto, 1996; Srinivasan and Hultin, 1995; Srinivasan and Hultin, 1997). Thus, detection of lipid peroxidation using TBARS and protein oxidation using PC were applied to the analysis of bonito muscle protein oxidation during storage. TBARS and $\mathrm{PC}$ of bonito muscle proteins were increased after storage for 4 days at $15^{\circ} \mathrm{C}$ (Figs. 1 and 2). Thus, these results suggested that the oxidative deterioration of proteins in bonito muscle had proceeded during a 4-day storage period. Similar results have been found regarding oxidative deterioration of proteins in fish muscle in previous reports (Saeed and Howell, 2002; Srinivasan and Hultin, 1995; Srinivasan and Hultin, 1997).

SDS-PAGE to detect FTSC-labeled proteins demonstrated the increase in the intensity of band of $36 \mathrm{kDa}$ with increasing storing days (Fig. 3). Further we investigated the protein oxidation pattern using 2D-GE (Fig. 4). The comparisons of total and FTSC-labeled proteins of the particular range $\left(36-60 \mathrm{kDa}\right.$ and $\left.\mathrm{pI} 6^{-9}\right)$ are shown in Fig. 5. The increase of the $\mathrm{PC}$ of this range was observed. This result obtained by 2D-GE corresponded with the SDS-PAGE results described above. Previously, it was reported that $\mathrm{PC}$ was detected in the same range in rainbow trout muscle using 2D immunoblotting (Kjærsgård and Jessen, 2004). However, this study showed that most of PCs were detected in the specific range $(36-60 \mathrm{kDa})$ of

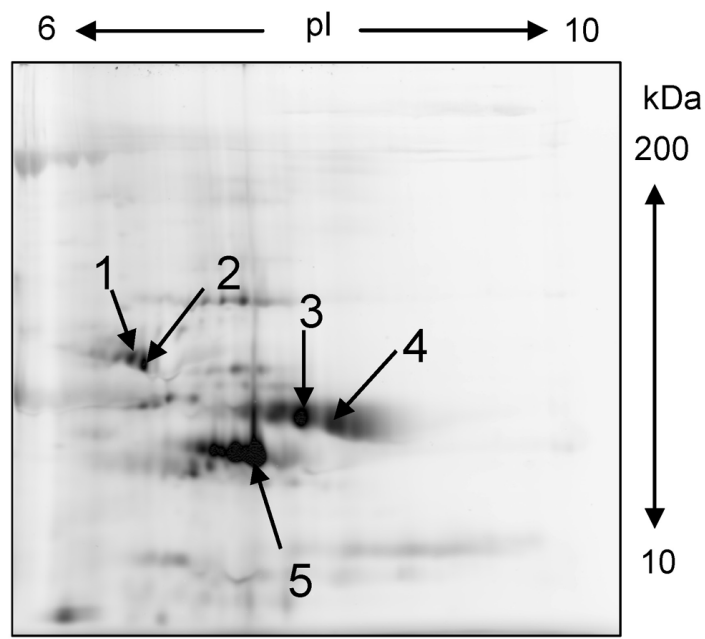

Fig. 6. 2D-GE pattern of muscle tissue proteins stored of bonito stored for 4 days. FTSC-labeled proteins are separated by a nonlinear $\mathrm{pH}$ 6-10 IPG dry strip, followed by a size separation on $10 \%$ SDS-PAGE. The five spots were picked up and identified by homology search.

Table 1. Protein identification by homology search.

\begin{tabular}{|c|c|c|c|}
\hline $\begin{array}{l}\text { Spot } \\
\text { no. }\end{array}$ & Protein & Accession no. & $\begin{array}{l}\text { Sequence } \\
\text { coverage }\end{array}$ \\
\hline 1 & $\begin{array}{l}\text { Unnamed protein product } \\
\text { [Tetraodon nigroviridis] }\end{array}$ & gi|47210809 & $44 \%$ \\
\hline 2 & Enolase 3 [Danio rerio] & gi 68086449 & $21 \%$ \\
\hline 3 & Aldolase A [Danio rerio] & gi|37595414 & $38 \%$ \\
\hline 4 & Aldolase [Ictalurus punctatus] & gi|27883578 & $50 \%$ \\
\hline 5 & $\begin{array}{c}\text { L-Lactate dehydrogenase A Chain } \\
\text { [Fundulus heteroclitus }]\end{array}$ & gi 6016487 & $23 \%$ \\
\hline
\end{tabular}

the muscle proteins of bonito stored at $15^{\circ} \mathrm{C}$, and protein oxidation and carbonylation proceeded preferentially in various abundant proteins (Figs. 4 and 5).

In order to further separate the oxidized proteins, the pI range of strip gels were changed to the narrow range (Fig. 6). Furthermore, the proteins were applied to $2 \mathrm{D}-\mathrm{GE}$ after solution-phase IEF fractionation using a ZOOM fractionator (Invitrogen). The pre-fractionation was available to concentrate low abundance proteins, and using narrow range strip gels conducted cluster of proteins to separate spots has been reported (Schulenberg and Patton, 2004; Zuo and Speicher, 2000). The aforementioned techniques were also effectively used in this study (Fig. 6). Using the results of MS and MS/MS analyses with MALDI-TOFMS, the five proteins among FTSC-labeled proteins were identified by the genome database of the NCBI as enolase 3, aldolase A, aldolase, L-lactate dehydrogenase A chain (LDH-A), and an unnamed protein product (Table 1). Enolase has been reported as an early marker of human myogenesis (Fougerousse et al., 2001). Aldolase has been reported as a biomarker of phylogenetic relationships and thermostability in fish (Tesk et al., 2001; Ahn et al., 2006). LDH has been reported as a biomarker 
associated with the metabolic phenotype of several human and mouse glioma cell lines (Griguer et al., 2005).

In this study, the early oxidative proteins of bonito muscle under storage conditions were investigated, and five proteins were identified using homology searching in genome database of the NCBI. We showed that proteomic technique was available to the food science field. Proteome analysis has previously revealed the changes in protein composition due to deterioration processes in several fish species (Martinez and Friis, 2004; Morzel et al., 2006; Morzel et al., 2000; Verrez-Bagnis et al., 2001; Kjærsgård et al., 2003). However, in those studies, easily oxidized proteins were not precisely identified using a genome database.

Proteomics are likely to be applicable to traceability in food processing, that is to say, in revealing the producing areas and breeding conditions of animal and plant products. The accumulation data for the genome database is necessary for the use of proteomic techniques in the field of food sciences. As food proteins are changed during processing and preserving, a database of related proteins will enable the technology of proteomics to become increasingly useful in food analysis in the future.

\section{References}

Ahn, B.-Y., Song. E.-S., Cho. Y.J., Kwon, O.W., Kim, J.K. and Lee, N. G. (2006). Identification of an anti-aldolase autoantibody as diagnostic marker for diabetic retinopathy by immunoproteomic analysis. Proteomics, 6, 1200-1209.

Ando, M., Toyohara, H., Shimizu, Y. and Sakaguchi, M. (1991). Post-mortem tenderisation of rainbow trout (Oncorhyncus mykiss) muscle caused by the gradual disintegration of the extracellular matrix structure. J. Sci. Food Agric., 55, 589-597.

Cserháti, T., Forgács, E., Deyl, Z. and Miksik, I. (2005). Chromatography in authenticity and traceability tests of vegetable oils and dairy products: a review. Biomed. Chromatogr., 19, 183-190.

Davies, K.J.A. (1987). Protein damage and degradation by oxygen radicals. J. Biol. Chem., 262, 9895-9901.

Davies, K.J.A., Delsignore, M.E. and Lin, S.W. (1987). Protein damage and degradation by oxygen radicals. J. Biol. Chem., 262, 9902-9907.

Fougerousse, F., Edom-Vovard, F., Merkulova, T., Merkulova, M. O., Durand, M., Butler-Browne, G. and Keller, A. (2001). The muscle-specific enolase is an early marker of human myogenesis. J. Muscle Res. Cell Motil., 22, 535-544.

Frankel, E.N. (1998). Food. In Lipid Oxidation, Frankel, E.N., Ed., Belland Bain: Glasgow, U.K.

Griguer, C.E., Oriva, C.R. and Gillespie, G.Y. (2005). Glucose metabolism heterogeneity in human and mouse malignant glioma cell lines. J. Neurooncol., 74, 123-133.

Hanash, S. (2003). Disease proteomics. Nature, 422, 226-232.

Harlizius, B., van Wijk, R. and Merks, J.W.M. (2004). Genomics for food safety and sustainable animal production. J. Biotechnol., $113,33-42$.

Jiang, S.-T., Wang, Y.-H.D., Gau, B.-S. and Chen, C.-S. (1990). Role of pepstatin-sensitive proteases on the postmortem changes of tilapia (Tilapia nilotica $\times$ Tilapia aurea) muscle myofibrils. J. Agric. Food Chem., 38, 1464-1468.

Jung, Y.-D., Chay, K.-O., Song, D.-U., Yang, S.-Y., Lee, M.-W. and Ahn, B. -W. (1997). Protein carbonyl formation in blood plasma by cephalosporins. Arch. Biochem. Biophys., 345, 311-317.

Kabisch, U.C., Gräntzdöffer, A., Schierhorn, A., Rücknagel, K.P., Andreesen, J.R. and Pich, A. (1999). Identification of D-proline reductase from clostridium sticklandii as a selenoenzyme and indications for catalytically active pyruvoyl group derived from a cysteine residue by cleavage of a proportion. J. Biol. Chem., 274, 8445-8454.

Kjærsgård, I.V.H. and Jessen, F. (2003). Proteome analysis elucidating post-mortem changes in cod (Gadus morhua) muscle proteins. J. Agric. Food Chem., 51, 3985-3991.

Kjærsgård, I.V.H. and Jessen, F. (2004). Two-dimensional gel electrophoresis detection of protein oxidation in fresh and tainted rainbow trout muscle. J. Agric. Food Chem., 52, 7101-7107.

Kosugi, H., Kojima, T. and Kikugawa, K. (1992). Interpretation of the thiobarbituric acid reactivity of rat liver and brain homogenates in the presence of ferric ion and ethylenediaminetetraacetic acid. Anal. Biochem., 202, 249-255.

Levine, R.L., Garland, D., Oliver, C.N., Amici, A., Climent, I., Lenz, A.-G., Ahn, B.-W., Shalitel, S. and Stadtman, E.R. (1990). Determination of carbonyl content in oxidatively modified proteins. Methods Enzymol., 186, 464-478.

Levine, R.L. and Stadtman, E.R. (2001). Oxidative modification of proteins during aging. Exp. Gerontol., 36, 1495-1502.

Martinez, I. and Friis, T.J. (2004). Application of proteome analysis to seafood authentication. Proteomics, 4, 347-354.

Morzel, M.,Verrez-Bagnis, V., Arendt, E.K. and Fleurence, J. (2000). Use of two-dimensional electrophoresis to evaluate proteolysis in salmon (Salmo salar) muscle as affected by a lactic fermentation. J. Agric. Food Chem., 48, 239-244.

Morzel, M., Chambon, C., Lefèvre, F., Paboeuf, G. and Laville, E. (2006). Modifications of trout (Oncorhynchus mykiss) muscle proteins by preslaughter activity. J. Agric. Food Chem., 54, 29973001.

Nakamura, A. and Goto, S. (1996). Analysis of protein carbonyls with 2,4-dinitrophenyl hydrazine and its antibodies by immunoblot in two-dimensional gel electrophoresis. J. Biochem., 119, 768-774.

Natarajan, S.S., Xu, C., Bae, H., Caperna, T.J. and Garrett, W.M. (2006). Characterization of storage proteins in wild (glycine soja) and cultivated (glycine max) soybean seeds using proteomic analysis. J. Agric. Food Chem., 54, 3114-3120.

Onodera, T. and Kim, C.-K. (2006). BSE situation and establishment of food safety commission in Japan. J. Vet. Sci., 7, 1-11.

O'Shannessy, D.J., Dobersen, M.J. and Quarles, R.H. (1984). A novel procedure for labeling immunoglobulins by conjugation to oligosaccharide moieties. Immunol. Lett., 8, 273-277.

Pafundo, S., Agrimonti, C. and Marmiroli, N. (2005). Traceability of plant contribution in olive oil by amplified fragment length polymorphisms. J. Agric. Food Chem., 53, 6995-7002.

Papa, I., Alvarez, C., Verrez-Bagnis, V., Fleurence, J. and Benyamin, Y. (1996). Post mortem release of fish white muscle $\alpha$-actinin as a marker of disorganisation. J. Sci. Food Agric., 72, 63-70.

Richards, M.P. and Dettmann, M.A. (2003). Comparative analysis of different hemoglobins: autoxidation, reaction with peroxide, and lipid oxidation. J. Agric. Food Chem., 51, 3886-3891.

Saeed, S., Fawthrop, S.A. and Howell, N.K. (1999). Electron spin resonance (ESR) study on free radical transfer in fish lipidprotein interaction. J. Sci. Food Agric., 79, 1809-1816.

Saeed, S. and Howell, N.K. (2002). Effect of lipid oxidation and frozen storage on muscle proteins of Atlantic mackerel (Scomber scombrus). J. Sci. Food Agric., 82, 579-586.

Schulenberg, B. and Patton, W.F. (2004). Combining microscale solution-phase isoelectric focusing with Multiplexed Proteomics ${ }^{\circledR}$ dye staining to analyze protein post-translational modifications. Electrophoresis, 25, 2539-2544.

Seki, N. and Watanabe, T. (1984). Connectin content and its postmortem changes in fish muscle. J. Biochem., 95, 1161-1167.

Shacter, E. (2000). Quantification and significance of protein oxidation in biological samples, Drug Metab. Rev., 32, 307-326.

Sikorski, Z.E. and Sun Pan, B. (1994). The effect of heat-induced 
changes in nitrogenous constituents on the properties of seafoods. In Seafoods: Chemistry, Processing Technology and Quality, Shahidi, F., Botta, J.R., Eds., Blackie Academic \& Professional: London, U.K.

Soyer, A. and Hultin, H.O. (2000). Kinetics of oxidation of the lipids and proteins of cod sarcoplasmic reticulum. J. Agric. Food Chem., 48, 2127-2134.

Srinivasan, S. and Hultin, H.O. (1995). Hydroxyl radical modification of fish muscle proteins. J. Food Biochem., 18, 405-425.

Srinivasan, S. and Hultin, H.O. (1997). Chemical, physical, and functional properties of cod proteins modified by a nonenzymic free-radical-generating system. J. Agric. Food Chem., 45, 310-320.

Stadtman, E.R. (1990). Metal ion-catalyzed oxidation of proteins: biochemical mechanism and biological consequences. Free Radic. Biol. Med., 9, 315-325.

Tejada, M., Careche, M., Torrejón, P., del Mazo, M.L., Solas, M.T., García, M.L. and Barba, C. (1996). Protein extracts and aggregates forming in minced cod (Gadus morhua) during frozen storage. J. Agric. Food Chem., 44, 3308-3314.

Terry, L.A., White, S.F. and Tigwell, L.J. (2005). The application of biosensors to fresh produce and the wider food industry. $J$. Agric. Food Chem., 53, 1309-1316.

Tesk, P.R., Cherry, M.I. and Matthee, C.A. (2004). The evolutionary history of seahorses (Syngnathidae: Hippocampus): molecular data suggest a West Pacific origin and two invasions of the Atlantic Ocean. Mol. Phylogenet. Evol., 30, 273-286.

Tsuchiya, H., Kita, S. and Seki, N. (1992). Postmortem changes in R-actinin and connectin in carp and rainbow trout muscles. Nippon Suisan Gakkaishi, 58, 793-798 (in Japanese).

Verrez-Bagnis, V., Ladrat, C., Morzel, M., Noël, J. and Fleurence, J. (2001). Protein changes in post mortem sea bass (Dicentrarchus labrax) muscle monitored by one- and two-dimensional gel electrophoresis. Electrophoresis, 22, 1539-1544.

Zuo, X. and Speicher, D.W. (2000). A method for global analysis of complex proteomes using sample prefractionation by solution isoelectrofocusing prior to two-dimensional electrophoresis. Anal. Biochem., 284, 266-278. 